pÿBiocultural diversity (BCD) in European cities interactions between motivations, experiences and environment in public parks

\author{
Vierikko, Kati
}

2020-02-01

Vierikko , K, Goncalves , P , Haase , D , Elands , B , loja , C , Jaatsi , M , Pieniniemi , M , Lindgren , J , Grilo , F , Santos-Reis , M , Niemelä , J \& Yli-Pelkonen , V 2020 , ' Biocultural pÿdiversity (BCD) in European cities interactions between motivations, experiences and environment in public parks ' , Urban Forestry \& Urban Greening , vol. 48 , 126501 . https://doi.org/10.1016/j.ufug.20

http://hdl.handle.net/10138/321152

https://doi.org/10.1016/j.ufug.2019.126501

CC BY-NC-ND

acceptedVersion

Downloaded from Helda, University of Helsinki institutional repository.

This is an electronic reprint of the original article.

This reprint may differ from the original in pagination and typographic detail.

Please cite the original version. 


\title{
Biocultural diversity (BCD) in European cities - interactions between motivations, experiences and environment in public parks
}

\author{
Vierikko, Kati ${ }^{\text {a }}$, Gonçalves, Paula ${ }^{\text {b; Haase, Dagmar }}{ }^{\text {c }}$; Elands, Birgit ${ }^{\text {d }}$ Ioja, Cristian ${ }^{\text {e }}$; Jaatsi, \\ Mia $^{\text {f }}$; Pieniniemi, Mari ${ }^{\text {g }}$; Lindgren, Jasmina ${ }^{\mathrm{g}}$; Grilo, Filipa ${ }^{\mathrm{b}}$; Santos-Reis, Margarida ${ }^{\mathrm{b}}$; \\ Niemelä, Jari ${ }^{\mathrm{h}}$; Yli-Pelkonen, Vesa ${ }^{\mathrm{g}}$
}

${ }^{\mathrm{a}}$ Finnish Environment Institute, Finland; Corresponding author: kati.vierikko@ymparisto.fi

${ }^{\mathrm{b}}$ Centre for Ecology, Evolution and Environmental Changes (cE3c), Faculdade de Ciências,

Universidade de Lisboa, Portugal

${ }^{\mathrm{c}}$ Humboldt Universität zu Berlin, Department of Geography, and Helmholz Centre for Environmental Research - UFZ, Department for Computational Landscape Ecology, Germany

${ }^{\mathrm{d}}$ Wageningen University \& Research, Netherlands

${ }^{\mathrm{e}}$ Department Regional Geography and Environment, University of Bucharest, Romania

${ }^{\mathrm{f}}$ Department of Geography and Informatics, Faculty of Science, University of Helsinki, Finland

${ }^{g}$ Ecosystems and Environment Research Programme, Faculty of Biological and Environmental Sciences, University of Helsinki, Finland

${ }^{\mathrm{h}}$ Faculty of Biological and Environmental Sciences and Helsinki Institute of Sustainability Science (HELSUS), University of Helsinki, Finland

\section{Accepted final draft version}

\section{Reference:}

Vierikko, K., Gonçalves, P., Haase, D., Elands, B., Ioja, I.C., Jaatsi, M., Pieniniemi, M., Lindgren, J., Grilo, F., Santos-Reis, M., Niemelä, J., Yli-Pelkonen, V. (2020) Biocultural diversity (BCD) in European cities - interactions between motivations, experiences and environment in public parks. Urban Forestry \& Urban Greening, in press.

http://doi.org/10.1016/j.ufug.2019.126501

\section{Disclaimer:}

The PDF document is a copy of the final version of this manuscript that was subsequently accepted by the journal for publication. The paper has been through peer review, but it has not been subject to any additional copy editing or journalspecific formatting. It thus looks different from the final published version, which may be accessed following the DOI above. 


\begin{abstract}
Urban green spaces (UGS) provide multiple benefits, and public parks in particular have a key role in supporting ecological and social sustainability in cities, contributing to humannature interactions. We studied the interrelationships between uses, experiences and the environment by adopting a novel concept of urban biocultural diversity (BCD). The concept identifies three interlinked spheres of urban BCD: materialised, lived and stewardship. We conducted place-based research in 33 parks located in four European capitals: Helsinki, Berlin, Bucharest and Lisbon. A total of 1474 visitors were interviewed concerning their motivations to use the park and their experiences during the visit. Using an open-ended survey, we revealed more than 50 motivations for park use and over 100 features people enjoyed during their visits. On the other hand, visitors mentioned far fewer things that disturbed them (60). We revealed that despite the fact motivations to use parks were strongly human-oriented, visitors widely enjoyed the environmental characteristics of parks, and especially nature. We found that parks located in neighbourhoods with low socio-economic status and outside the central area of the city were structurally less diverse than parks located in the city core. The structurally diverse parks enhanced motivations to use them, and increased overall enjoyments of the environment. We revealed clear differences in motivations and enjoyments between cities, implying that the day-to-day practices of people using and experiencing nature varies between cities.
\end{abstract}

\title{
Keywords:
}

Biocultural diversity, interlinkage, place-based research, public parks, urban green spaces 


\section{Introduction}

1.1 The importance of urban green spaces for cities and citizens

Our world is facing rapid urbanisation. Nowadays urban residents spend most of their time in human-constructed environments (Matz et al., 2015). Consumer-oriented lifestyles in densely built-up urban areas do not support multi-sensory engagement with the natural environment, e.g. listening to birds or following seasonal changes (Pretty et al., 2009; Puppim de Oliveira et al., 2011; Soga \& Gaston, 2016; Stokols, 2018). Urban green spaces (UGS) such as forests, public parks or community gardens provide diverse opportunities for residents to interact with nature, and for human-oriented activities such as exercise, relaxing or meet other people (Vertovec, 2007; Kabisch et al., 2014; Elands et al., 2018a). The benefits of UGS are widely acknowledged as they contribute to climate change adaptation, local biodiversity conservation, social cohesion and the well-being of residents (Bratman et al., 2012; Hartig et al., 2014; Kabisch et al., 2014; Hansen \& Pauleit, 2014; Nielsen et al., 2014; Betram \& Rehdanz., 2015; Pauleit et al., 2017). The ways in which cities and their green spaces are planned and developed have a considerable effect on the accessibility to use and enjoy the benefits provided by UGS. With a decreasing amount of free spaces in densely-built growing cities, urban planners and policy-makers address the importance of planning concepts such as urban green infrastructure (UGI) and strategies for multifunctional UGS (Hansen \& Pauleit, 2014; Pauleit et al., 2017).

Multifunctionality of parks represents the capacity of UGS to provide several ecological, socio-cultural and economic benefits concurrently, while avoiding conflicts and trade-offs (Sussams et al., 2015; Hansen et al., 2016). Park characteristics such as vegetation structure, facilities and services have a key role in supplying multifunctionality (McCormack, 2010; Konijnendijk et al., 2013; Voigt et al., 2014; Schetke et al., 2014). However, green spaces have often been introduced as undifferentiated and uniform spaces, focusing on facilities and services, with little attention paid to the level of vegetation structure or biodiversity of parks (Ives et al., 2017). Recent studies have revealed that diverse vegetation can make green spaces more attractive and restorative (Fuller et al., 2007; Hoyle et al. 2017, 2019), and biotope and plant species richness of UGS is highly appreciated (Voigt and Wurster, 2015; Fischer et al. 2018a). However, on-site experiences (either positive or negative) are also dependent on the specific context of visits (Qiu et al., 2013). Each green space is located in a 
specific urban context and has unique environmental characteristics that influence how people use, experience or perceive its benefits (Hoyle et al. 2019). Although there are several studies focusing on human-biodiversity interactions within parks, comparatively little is known about the different motives to use green spaces in relation to the on-site experiences of visitors. It is unclear how activities such as walking a dog, meeting friends or relaxing are connected with actual experiences, and what the role of park characteristics in these interconnections is (e.g. Dallimer et al., 2012; Botzat et al., 2016; Palliwoda et al., 2017; Fischer et al., 2018a). A biocultural diversity (BCD) approach offers a novel way to study these relationships and the multifunctionality of UGS.

\subsection{Biocultural diversity and urban green spaces}

To analyse multi-dimensional relationships between people and nature in cities, a framework of biocultural diversity (BCD) for the urban context has been developed (Vierikko et al., 2017a; Elands et al., 2018b). Originally, the concept of BCD was developed in the 1990s in order to denote the diversity of life in all its manifestations - biological, cultural and linguistic - which co-evolve within complex socio-ecological systems (Maffi, 2012). BCD focuses on interrelationships and interdependencies between people and nature, and diverse ways in which people live with nature (Buizer et al., 2016). Elands et al. (2018b) and Vierikko et al. (2017a) identified three interlinked spheres for human-nature relationships: materialised, lived and stewardship. Lived BCD is the central sphere as it refers to the day-to-day practices of people using and experiencing nature in cities. It concerns interrelationships between people and nature, as well as perceived and experienced nature, while acknowledging diversity as an inherent entity of BCD (Vierikko et al., 2017b). While lived BCD is primarily mediated through experiences and perceptions, stewardship BCD is an active, conscious engagement in the shaping of such assemblages (Elands et al., 2018b). Materialised BCD primarily refers to the tangible expressions of human-nature interactions and socio-ecological processes (Elands et al., 2018b). Cultural landscapes, of which we have many in Europe, where biodiversity was modulated over centuries by traditional agricultural practices, is one example of materialised BCD (White, 2004; Taylor \& Lennon, 2011; Pungetti, 2013; Elands et al., 2018b). Structural characteristics such as vegetation, cultural artefacts and facilities manifest the human-nature relationship of a single UGS. However, materialised BCD is more than a sum of its measured tangible elements; it also relates to the history of UGS, articulating previous political, sociocultural and economic conditions (Byrne and Wolch, 2009; Millard, 2010). 
As our study is aimed at giving a more explicit picture of the relationships between motivations, experiences and park characteristics, our focus is on lived and materialised BCD and not on active engagement with nature (stewardship BCD). Lived BCD in our study refers to motivations to use parks and experiences during the park visit. We were especially interested in the diversity of motivations and experiences, and the interlinkages between them. Materialised BCD was studied through structural characteristics of parks (biotopes, vegetation, facilities, cultural artefacts), taking the surrounding urban context into account. As our study wants to study motives and experiences during the actual park visit, we chose a place-based research approach to analyse lived and materialised BCD in public parks (Elands et al., 2015; Buizer et al., 2016; Vierikko et al., 2016; Balvanera et al., 2017). The place-based focus was further strengthened by the selection of a variety of parks within four European cities that cover a geographical range from north(-east) to south(-west), including very different development paths and histories of the cities. We defined a park as a publicly accessible green area within a city that is intended for recreational use by urban dwellers and includes a wide range of biophysical and cultural elements, such as trees, shrubs, flowering plants, mown lawns, playgrounds, water bodies and sculptures (Cvejić et al., 2015). The main objectives of this study are:

- What are main motivations to use parks and how are they connected with actual experiences?

- Do motivations and experiences change along with the structural characteristics of parks?

- Do interlinkages of motivations and experiences differ between cities?

Figure 1 visualises the interrelations between our main analytical concepts. 
Urban context: Geographical location (Helsinki, Lisbon, Bucharest, Berlin), location of park in the city, population density and socio-economic status of neighbourhood
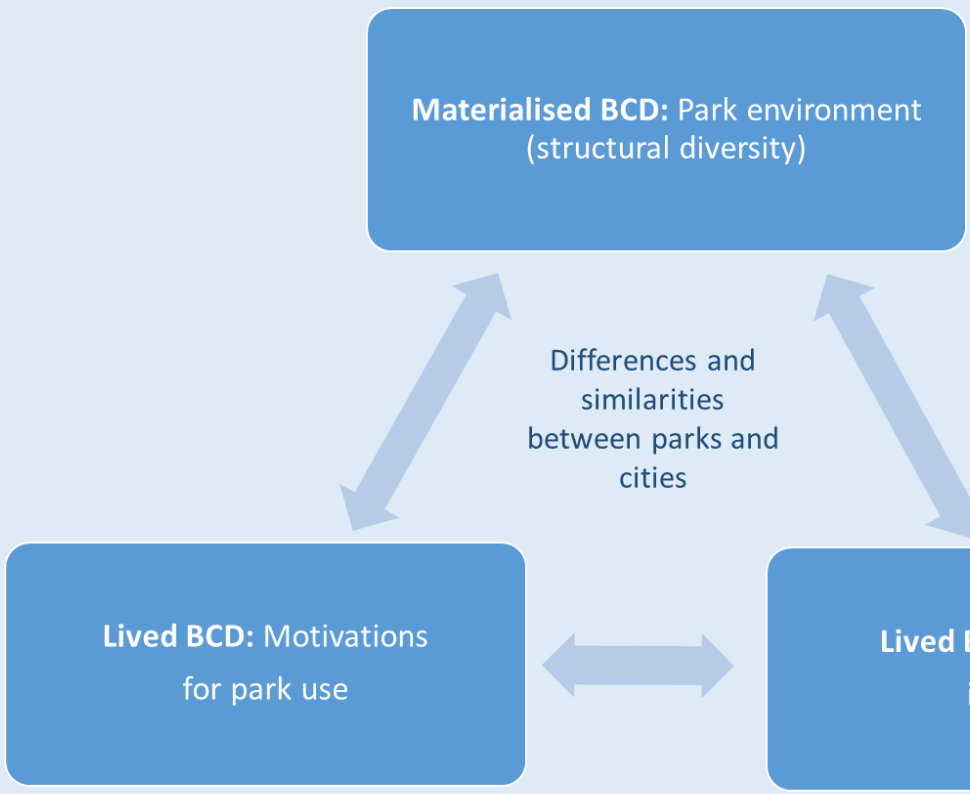

Lived BCD: Experiences

in the park

Figure 1. Framework for park visitor research, inspired by the biocultural diversity approach as developed by Elands et al., 2018 and Vierikko et al. (2017a). Every park is located in a unique urban context, has specific characteristics (materialised BCD) and is used and experienced in a variety of ways (Lived BCD).

\section{Methods}

\subsection{Materialised BCD: Park characteristics}

The research was conducted in 33 publicly accessible parks in four European capitals: Helsinki (Finland), Berlin (Germany), Bucharest (Romania) and Lisbon (Portugal), as part of the EU FP7 GREENSURGE research project (2013-2017). The methodological design was developed by the Universities of Helsinki (UH) and Lisbon (FCUL) and also applied by teams at Humboldt University Berlin (HUB) and the University of Bucharest (UB). The studied parks needed to fulfil certain criteria: they are publicly accessible, intended for recreational use, and include a variety of biophysical and other structural characteristics. The studied parks represent a gradient of urbanisation and cover a variety of designs, facilities and neighbourhoods, from city centre to suburbs, except in Berlin where all the studied parks were situated in the dense urban area. Furthermore, the selected parks needed to represent 
neighbourhoods with varying socio-economic status. Due to the limited resources available (labour and financial), in Berlin and Bucharest fewer parks were selected: three parks in Berlin and six in Bucharest. The specific location of all the studied parks can be found on Google map: (https://drive.google.com/open?id=1u68fx_gi52YodcK9o8cj7ujWoCs\&usp=sharing).

We investigated the structural diversity of parks by measuring the number of biotopes, facilities, services and artificial elements, and estimating density of vegetation structure. We then gave a qualitative value (low - medium - high) for each structural characteristic relative to the size of park, except for biotopes (Table 1). Moreover, we identified the locations of the studied parks along the gradient from city centre towards the periphery, the population density and the socio-economic status of the surrounding neighbourhoods (Table 1). Tangible characteristics and the surrounding urban contexts at park level are presented in Supplementary Table 1. 
Table 1. Four structural characteristics (biotopes, vegetation structure, facilities and services, artificial elements) identified in 33 parks describing the structural diversity of the park and three variables (population density, socio-economic status, gradient) for the surrounding urban context, and a description of values used in the analyses.

\begin{tabular}{|c|c|c|}
\hline Structural diversity & Value & Description of value \\
\hline $\begin{array}{l}\text { Biotopes: } \\
\text { Woody patch, wetland, } \\
\text { meadow, lawn, flower- } \\
\text { bed, pond }\end{array}$ & $0-6$ & The number of biotopes in the park \\
\hline $\begin{array}{l}\text { Vegetation structure: } \\
\text { Vertical and structural } \\
\text { density of vegetation }\end{array}$ & $\begin{array}{l}1 \\
2 \\
3\end{array}$ & $\begin{array}{l}\text { Low vegetation with sparse density (few trees) } \\
\text { Medium dense with some large trees and shrubs } \\
\text { Dense and multi-layered vegetation }\end{array}$ \\
\hline $\begin{array}{l}\text { Facilities \& services: } \\
\text { Benches, cafes, playgrounds, } \\
\text { sports equipment, dog } \\
\text { areas, social games }\end{array}$ & $\begin{array}{l}1 \\
2 \\
3\end{array}$ & $\begin{array}{l}\text { Park has few benches or other facilities } \\
\text { Park has many benches and few other facilities } \\
\text { Park has many different kinds of facilities \& services }\end{array}$ \\
\hline $\begin{array}{l}\text { Artificial elements: } \\
\text { Artistic works, buildings, } \\
\text { constructed water } \\
\text { elements, statues }\end{array}$ & $\begin{array}{l}1 \\
2 \\
3\end{array}$ & $\begin{array}{l}\text { Park has few artificial elements } \\
\text { Park has some artificial elements } \\
\text { Park has many different artificial elements }\end{array}$ \\
\hline Urban context & Value & Description of value \\
\hline $\begin{array}{l}\text { Population density: } \\
\text { Permanent residents living } \\
\text { nearby the park }\end{array}$ & $\begin{array}{l}2378- \\
23233\end{array}$ & $\begin{array}{l}\text { Population density }(\mathrm{km} 2) \text { within } \\
500 \text { m radius of the park }\end{array}$ \\
\hline $\begin{array}{l}\text { Socio-economic status: } \\
\text { Overall socio-economic } \\
\text { status of neighbourhood the } \\
\text { park is situated in based on } \\
\text { general statistics of ave- } \\
\text { rage income. }\end{array}$ & $\begin{array}{l}1 \\
2 \\
3 \\
4 \\
5\end{array}$ & $\begin{array}{l}\text { Low } \\
\text { Medium-low } \\
\text { Medium } \\
\text { Medium-high } \\
\text { High }\end{array}$ \\
\hline $\begin{array}{l}\text { Gradient: } \\
\text { Distance from the park to } \\
\text { the central area of city }\end{array}$ & $\begin{array}{l}1 \\
2 \\
3\end{array}$ & $\begin{array}{l}\text { Central area } \\
\text { Semi-central } \\
\text { Suburb or periphery }\end{array}$ \\
\hline
\end{tabular}

\subsection{Exploring lived BCD of parks}

We conducted an on-site questionnaire with open-ended questions with visitors in the 33 studied parks. The survey followed a qualitative approach with open questions allowing respondents to express their motivations and experiences in their own words, which are 
commonly lost with pre-determined response categories. Our questionnaire was based on earlier studies in the field of place-based research (Vierikko \& Yli-Pelkonen, 2019). By choosing an on-site study method, the researcher is part of the actual experience and the responses reflect the respondents' multiple experiences in real-life situations (Elands et al., 2018b). We conducted the survey in Helsinki and Lisbon in the summer of 2015, and in Berlin and Bucharest in the summer of 2016. We interviewed visitors during weekdays and weekends, while avoiding extreme weather conditions (rainy, hot $\left(>30^{\circ} \mathrm{C}\right.$ ) and cold $\left.\left(<10^{\circ} \mathrm{C}\right)\right)$ and times of public events in the parks. We approached park visitors of different ages (over 13 years) and gender, and identified ethnicity to achieve a truly representative sample of park visitors. Foreign tourists were excluded, and we only interviewed people who currently lived in the relevant country. We asked if the park visitors would like to respond to the survey and briefly explained the research. In total, 1474 visitors accepted the invitation to respond to the survey.

The questionnaire covered several topics regarding the motivation for visit, frequency of park use, experiences, perceived biodiversity and well-being, as well as the visitor's sociodemographic and cultural background, e.g. gender, age, marital status, education level and birth country. However, for the purpose of this paper, the analyses were limited to motivations and park experiences. Table 2 shows how the open questions were formulated and answers interpreted. The responses were content-analysed by local researchers in each study country. Different motivations and experiences were then coded under descriptive themes. The themes were inductively developed based on the answers. The themes and codings of open answers were agreed and synchronised between research teams in different cities. Detailed results of motivations and experiences at park level are provided in Supplementary Table 2. We computed correlations among variables by using Spearman's non-parametric test. Statistically significant differences between different types of parks and cities were tested using the Kruskal-Wallis non-parametric test. All statistical testing was performed using IBM SPSS Statistics 24 and R Studio.

Table 2. Characteristics of questionnaire with respect to park use and experience. 


\begin{tabular}{|c|c|c|}
\hline Question asked by interviewer & Type of question and coding the answer & Categorising the answers \\
\hline $\begin{array}{l}\text { As for today, why did you come } \\
\text { (what you are planning to do) to } \\
\text { the park? }\end{array}$ & $\begin{array}{l}\text { Open-ended: respondent could mention } \\
\text { more than one motivation for arrival in } \\
\text { their own words. All mentioned reasons } \\
\text { were coded as } 0 \text { (not mentioned) or } 1 \\
\text { (mentioned) for every respondent. }\end{array}$ & $\begin{array}{l}\text { All mentioned motivations were } \\
\text { grouped under the themes that were } \\
\text { inductively developed and } \\
\text { synchronized by researchers in four } \\
\text { cities. }\end{array}$ \\
\hline $\begin{array}{l}\text { What do you enjoy during your } \\
\text { visit? }\end{array}$ & $\begin{array}{l}\text { Open-ended: respondent could mention } \\
\text { several things they enjoyed in their own } \\
\text { words. All mentioned enjoyable aspects } \\
\text { were coded as } 0 \text { (not mentioned) or } 1 \\
\text { (mentioned) for every respondent. }\end{array}$ & $\begin{array}{l}\text { All mentioned enjoyments were } \\
\text { grouped under the themes that were } \\
\text { inductively developed and } \\
\text { synchronized by researchers in four } \\
\text { cities. }\end{array}$ \\
\hline $\begin{array}{l}\text { Is/was there anything disturbing } \\
\text { you during your visit? }\end{array}$ & $\begin{array}{l}\text { Open-ended: respondent could mention } \\
\text { several things they are disturbed. All } \\
\text { mentioned disturbing things were coded as } \\
0 \text { (not mentioned) or } 1 \text { (mentioned) for } \\
\text { every respondent. }\end{array}$ & $\begin{array}{l}\text { All mentioned disturbing factors were } \\
\text { grouped under the themes that were } \\
\text { inducitvely developed and } \\
\text { synchronized by researchers in four } \\
\text { cities. }\end{array}$ \\
\hline
\end{tabular}

\section{Results}

\subsection{Motivations and linkages with experiences}

Overall, park visitors mentioned over 50 different motivations for their visit. We grouped them under nine themes: (1) social relations, (2) mobility-based recreation, (3) stationarybased recreation, (4) relaxation \& well-being, (5) park characteristics, (6) nature-related, (7) facilities \& services, (8) location of park, and (9) weather (Table 3). People were mostly motivated by mobility-based recreation $(n=515)$, such as walking a dog, exercise, walking in the park (Table 3, Fig. 2). Social relations (meeting friends or having a picnic) were the second most important motivation for park use $(n=370)$. Crossing the park on the way to somewhere else or using the park due to close-to-home location were also mentioned quite often $(n=282)$. The park visitors frequently expressed multiple motivations for their arrival, ranging between 1 to 7 reasons, and on average having 1.4 reasons. 'Walk \& talk' (with friend/spouse) was an example of a social relation linked with mobility-based recreation. Many respondents mentioned multiple reasons such as 'meeting friends, playing and relaxing' or 'good weather, relaxing and nice to watch people'. In all three of these examples social relations were involved, but from different aspects: the first two examples described the park as a place to meet friends or other familiar people, while the latter was related to social life at the park.

Further analysis of the different themes of motivations and experiences revealed two key domains: human and environment. We grouped the first four themes under the human 
domain, which included motivations that emerged from personal properties or social dimensions following theories of place meaning and sense of place (Sixsmith, 1986; Gustafsson, 2001). Park characteristics, nature-related, facilities and services were grouped under the environment domain as they represent tangible or intangible (e.g. clean air) characteristics of the park.

Only 212 visitors (12\%) mentioned environment-based motivations for their visit, and within this domain, 74 people mentioned nature-related motivations for their visit. 'Watching birds' or 'feeding ducks' were commonly mentioned nature-related activities and 'breathing fresh air' can be understood as a nature-based benefit provided by the park. Environment-based motivations were linked with relaxation at the park in general, but often also with the specific location of the park. The location of the park and weather were frequently mentioned together.

Regarding the enjoyed experiences of respondents during their visit, overall, more than 100 different tangible and intangible features were mentioned. Similarly to motivations, we grouped the enjoyed aspects under nine themes and two domains (Table 3). Categorising motivations and enjoyments under the same themes helped us to reveal interlinkages between human- and environment-based motivations and enjoyments (see Fig. 3). The park visitors strongly expressed enjoying the tangible characteristics of the parks. Almost half of all respondents $(n=729)$ mentioned enjoying the nature or special natural elements at the park, such as vegetation, trees, flowerbeds and birds, but also naturalness, overall greenness and seasonal changes in the trees. Specific park characteristics such as beauty, cleanliness, design or park size and more intangible characteristics such as 'diverse' or 'atmosphere' were comparatively often mentioned by the park visitors $(n=677)$. The park visitors commonly mentioned more than one thing they enjoyed, varying between 0-13 features. More than half $(n=789)$ mentioned at least two enjoyments, and on average they mentioned 2.1 features. Only 31 visitors (2\%) did not enjoy anything in the park. 
Table 3. Nine themes of motivations for park use and enjoyments during the visit and examples of mentions $(\mathrm{N}=1474)$.

\begin{tabular}{|c|c|c|c|}
\hline & Theme & Human-based motivations & Human-based enjoyments \\
\hline \multirow{5}{*}{ 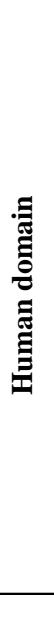 } & Social relations & $\begin{array}{l}\text { Spend time with friends, see friends, meet } \\
\text { someone, play with children, date, picnic, } \\
\text { enjoy company, watch other people }\end{array}$ & $\begin{array}{l}\text { People, a lot of people, different people, company, } \\
\text { meeting place, park life, sense of community, cultures, } \\
\text { religious together, absence of certain groups, have fun } \\
\text { (with others), watch other people, relaxed people in a } \\
\text { good mood, young and old people }\end{array}$ \\
\hline & $\begin{array}{l}\text { Mobility-based } \\
\text { recreation }\end{array}$ & $\begin{array}{l}\text { Walk a dog, excercise, sport, train, walk, } \\
\text { outdoor recreation, play (e.g. football), fly a } \\
\text { helicopter, catch Pokemons }\end{array}$ & Walk a dog, play, run, bike, sports \\
\hline & $\begin{array}{l}\text { Stationary-based } \\
\text { recreation }\end{array}$ & $\begin{array}{l}\text { To eat (lunch/ ice-cream), drink (beer/ } \\
\text { coffee), listen music, work, lay down, study, } \\
\text { read, sit }\end{array}$ & Sit, read (a good book) \\
\hline & $\begin{array}{l}\text { Relaxation \& well- } \\
\text { being }\end{array}$ & $\begin{array}{l}\text { To relax, stroll, refresh, memorize, escape } \\
\text { something, recover from hangover, smoke a } \\
\text { joint }\end{array}$ & $\begin{array}{l}\text { Easy go, hang around, just be, meditation, refresh, stress } \\
\text { relief, empower, freedom, feel satisfied with life, } \\
\text { freedom, be alone, relax, no city stress, memories }\end{array}$ \\
\hline & Theme & Environment-based motivations & Environment-based enjoyments \\
\hline \multirow{4}{*}{ 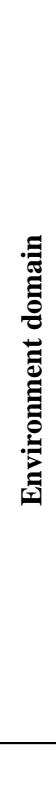 } & Park characteristics & $\begin{array}{l}\text { For park itself, atmosphere, enough space } \\
\text { around, familiar park, quietness }\end{array}$ & $\begin{array}{l}\text { The whole park, large size, more space, environment, } \\
\text { openess, less crowed, landscape, atmosphere, designed } \\
\text { park, slides, "true" park, modern park, historical value, } \\
\text { dynamic, diversity, harmony, symmetry, speciality, well- } \\
\text { managed, not too designed, informal, clean, private, } \\
\text { child-friendly, dog-friendly, safety, international, } \\
\text { japanese, urban, soundscape, beauty }\end{array}$ \\
\hline & Nature related & $\begin{array}{l}\text { To enjoy nature, watch birds, feed ducks, } \\
\text { watch horses/ponies, enjoy smells, fresh air }\end{array}$ & $\begin{array}{l}\text { Nature, diverse nature, naturlness, greenness, beauty of } \\
\text { nature, park lives along seasons, vegetation, estate } \\
\text { garden, forest, oak forest, trees, signing trees, shrubs, } \\
\text { meadow, flowers, lawn, edible plants, mushrooms, sea, } \\
\text { lake, pond, brook, water's edge, animals, rocks, small } \\
\text { wild area, shadow, clean air, scents of nature, sound of } \\
\text { water }\end{array}$ \\
\hline & Facilities \& services & $\begin{array}{l}\text { For (cultural organized) event, cafe services, } \\
\text { buy drugs, watch statues }\end{array}$ & $\begin{array}{l}\text { Playgrounds, sand field, walking route, sport facilities, } \\
\text { equipment for children, benches, dog facilities, cultural } \\
\text { events, museum, fountain, monuments, art works, } \\
\text { music, cafe, urban farming boxes, estate building, water } \\
\text { pool, bulevards, pavillion, water towel, toilets, bridges }\end{array}$ \\
\hline & Theme & Other motivations & Other enjoyments \\
\hline \multirow{2}{*}{$\stackrel{0}{0}$} & Location & $\begin{array}{l}\text { Cross the park, walk through, location close- } \\
\text { to-home }\end{array}$ & $\begin{array}{l}\text { Central, near-by home, location, middle of densely built } \\
\text { area, good access }\end{array}$ \\
\hline & Weather & To enjoy sun, good weather, sun bathing & Sun, good weather, summer \\
\hline
\end{tabular}




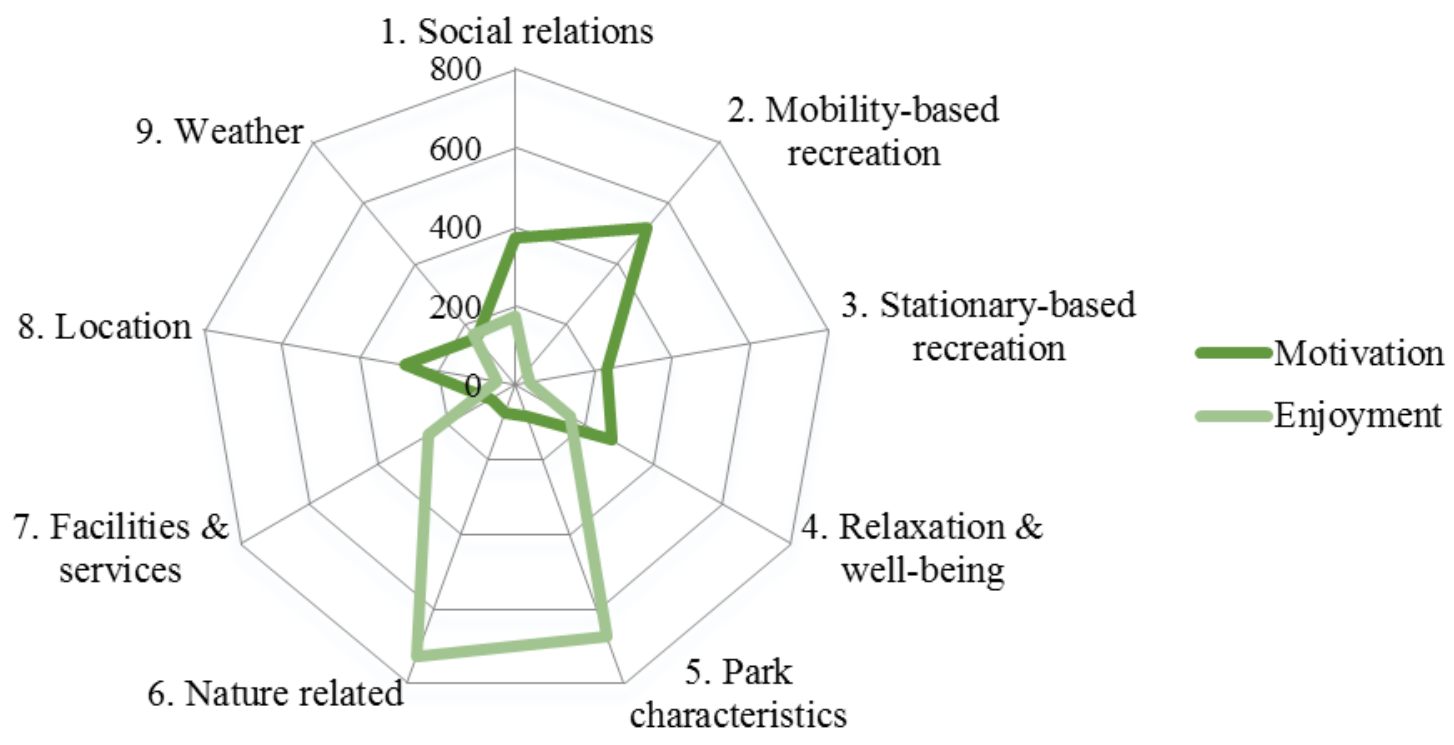

Figure 2. Number of visitors who mentioned at least one aspect under the nine themes of motivations (dark green) and enjoyments (bright green) $(\mathrm{N}=1474)$.

As Fig. 2 depicts, motivations for park visits were strongly human-based, while enjoyments were mainly environment-based. Overall, regardless of the reason for their arrival, the great majority of park visitors mentioned enjoying aspects of the environmental domain: park characteristics, nature, or facilities and services; however, to a varying degree under different themes of motivations (Fig. 3). Facilities and services were enjoyed less (12-35\%) than nature (31-54\%) or other park characteristics (39-50\%) under all motivation themes. Those respondents who were motivated to use the park due to nature enjoyed environmental characteristics more often than other respondents. On the contrary, those whose motivations for visiting were linked to facilities and services enjoyed the nature or park characteristics the least, and more often enjoyed the facilities and services (35\%) than visitors mentioning other motivational themes. Relaxation and well-being and mobility-based recreation among humanbased motivations were more often linked with enjoyment of nature (54\% and 52\%), while those who visited for social or stationary-based reasons enjoyed nature to lesser extent $(45 \%$ and $43 \%$, respectively). 

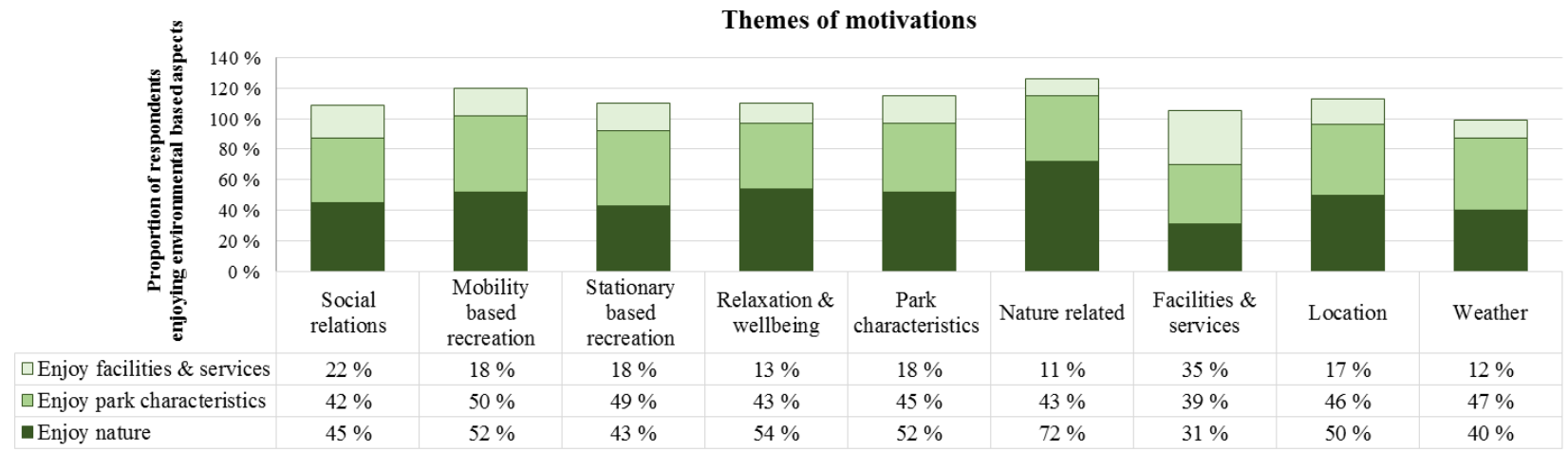

Figure 3. Proportion (\%) of respondents who enjoyed nature, park characteristics and facilities \& services under the different themes of motivations (social relations, mobilitybased, stationary-based recreation, relaxation \& well-being, park characteristics, nature related, facilities \& services, location, weather) $(\mathrm{N}=1474)$.

Visiting parks generated positive and negative experiences (Table 4). Half of the visitors ( $\mathrm{n}=$ 712) were disturbed by something, mostly by other people, poor quality of the park, or a lack of facilities and maintenance in the park. 'Disturbed by people' referred to misbehaviour of other visitors ('vandalism, drug dealers') or solely to the presence of different users, e.g. cyclists or certain social groups. Only 77 visitors were disturbed by nature itself, e.g. lack of specific natural elements (trees) or poor water quality of the lake in the park (Table 4).

Table 4. Four types of disturbances, examples of disturbing things and number of visitors (n) mentioning at least one type $(n=1474)$. 


\begin{tabular}{llc}
\hline Type & Disturbing things & Visitors (n) \\
\hline People & Cyclists, alcoholics, vandalism, crowded, too & 323 \\
& many joggers, kids, guardians, some people, \\
& disturbing behaviour, other groups, police, \\
& restlessness, drug selling, pickpockets, \\
& misbehaviour of others, annoying residents \\
& who know it better \\
\hline Park characteristics and & $\begin{array}{l}\text { Dogs excrements, trash, bad water quality in } \\
\text { management }\end{array}$ & $\begin{array}{l}\text { the water pond, broken glasses, fountains that } \\
\text { don't work, park degradation, low level of } \\
\text { management, no water in the pool, unmown }\end{array}$ \\
& $\begin{array}{l}\text { lawn, lack of facilities or services, bad } \\
\text { illumination, too silent, noises }\end{array}$ \\
\hline Nature related & $\begin{array}{l}\text { Lack of trees, lack of vegetation, lack of } \\
\text { shadows(feral) dogs, water quality of lake, } \\
\text { mosquitos, insects, geese, rabbits, messy } \\
\text { brook }\end{array}$ \\
\hline Cultural events & $\begin{array}{l}\text { Festivals, events, closing the park due to } \\
\text { festival }\end{array}$ \\
\hline
\end{tabular}

To understand linkages between motivations and experiences, we calculated correlations among these variables (Table 5). The results revealed that the enjoyments mentioned increased slightly with the mentioned motivations. The mentioned enjoyments increased significantly with environment-based motivations, but not with human-based motivations for visiting the park. The mention of disturbing factors decreased with human-based motivations to use parks, but increased with weather and location-based motivations. Environment-based motivations correlated positively with location-based motivations, while human-based motivations correlated negatively. Location- and weather-based motivations correlated highly positively.

Table 5. Spearman's rho correlations between average number of motivations (Motivations), enjoyments (Enjoyments) and disturbances (Disturbances), proportion of respondents mentioning human- (HumanM), environmental- (EnvironmentM), location- (LocationM) and weather- (WeatherM) based motivations to use parks, proportion of respondents mentioning human- (HumanE), environmental- (EnvironmentE) and nature- (NatureE) based enjoyments at the park level $(n=33)$. EnvironmentE includes nature relations explaining high correlation between these variables. 


\begin{tabular}{|c|c|c|c|c|c|c|c|c|c|c|}
\hline & 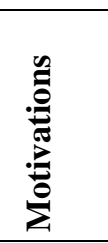 & 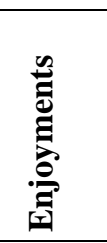 & 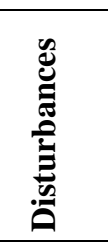 & 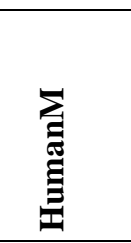 & 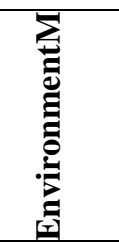 & 音 & 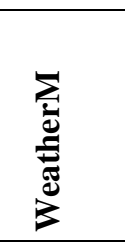 & 息 & 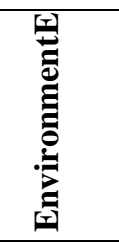 & 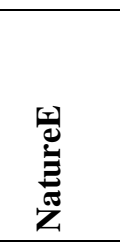 \\
\hline Motivations & 1.000 & $0.404^{*}$ & -0.216 & 0.340 & 0.293 & -0.248 & -0.102 & 0.116 & 0.198 & 0.144 \\
\hline Enjoyments & & 1.000 & -0.103 & -0.052 & $0.679 *$ & 0.144 & 0.058 & $0.454^{* *}$ & 0.329 & $0.344^{*}$ \\
\hline Disturbances & & & 1.000 & $-0.460^{* * *}$ & 0.143 & $0.486^{* * *}$ & $0.472^{* * *}$ & 0.064 & -0.287 & -0.037 \\
\hline HumanM & & & & 1.000 & -0.334 & $-0.720^{* * *}$ & $-0.755^{* *}$ & -0.035 & 0.104 & -0.152 \\
\hline EnvironmentM & & & & & 1.000 & $0.381^{*}$ & 0.265 & $-0.399^{*}$ & 0.121 & 0.270 \\
\hline LocationM & & & & & & 1.000 & $0.574^{* * *}$ & -0.035 & 0.048 & 0.205 \\
\hline WeatherM & & & & & & & 1.000 & 0.092 & -0.286 & 0.036 \\
\hline HumanE & & & & & & & & 1.000 & $-0.368^{*}$ & $-0.351^{*}$ \\
\hline EnvironmentE & & & & & & & & & 1.000 & $0.683^{* * *}$ \\
\hline NatureE & & & & & & & & & & 1.000 \\
\hline
\end{tabular}

*. Correlation is significant at the 0.05 level (2-tailed).

**. Correlation is significant at the 0.01 level (2-tailed).

3.3. Relationship between motivations, experiences and park characteristics

We grouped the parks into four types (Fig. 4) based on their structural diversity (2.1 and Supplementary Table 1). The typology might be considered reflective rather than definitive, allowing us to explore whether tangible characteristics of parks are linked with motivations or experiences. The first group, 'parks with low structural diversity', consisted of parks that had 1-2 different biotopes, the vegetation structure was rather simple and there were few facilities and artificial elements. The second group, 'parks with moderate structural diversity', was the largest group $(\mathrm{n}=12)$ including parks with few biotopes and a moderate level of vegetation structure, facilities and artificial elements. The third group, 'parks with high/medium-high structural diversity', included six parks that had different biotopes, the vegetation structure was rather diverse, but with a moderate level of facilities and artificial elements. The fourth and final group, 'parks with high structural diversity', consisted of structurally diverse parks in all aspects: biotopes, vegetation, facilities and artificial elements. These parks often represent old and well-known parks. 

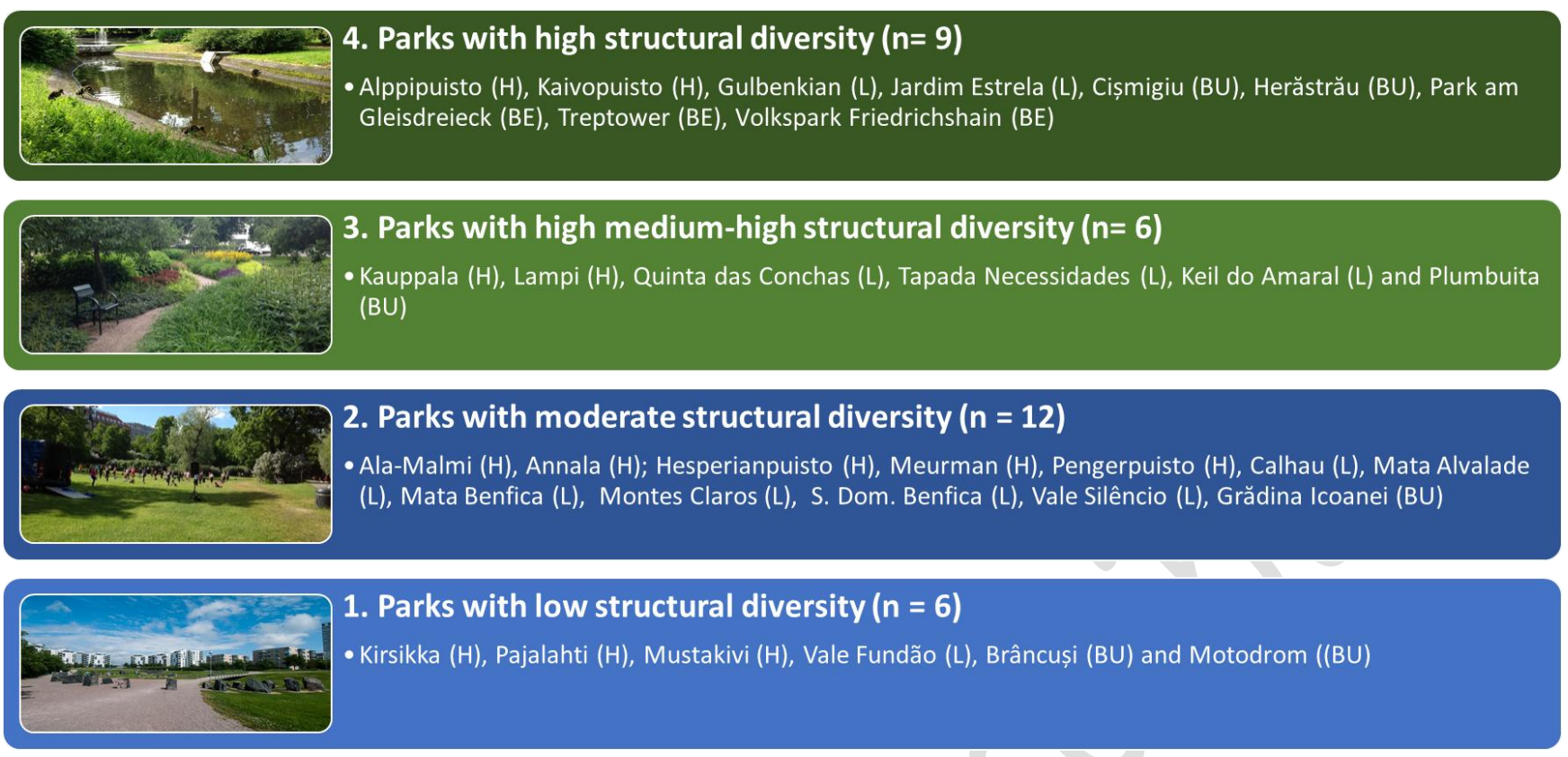

Figure 4. Typology of materialised biocultural diversity (BCD) for 33 studied parks in four European cities: Helsinki (H), Berlin (BE), Bucharest (BU) and Lisbon (L).

As our typology was inductively constructed, we checked its internal consistency by means of correlating the typology and its constituting elements (Fig. 5). Spearman's rho correlation revealed significant and strong positive correlations between the type of park and variables indicating structural diversity: number of biotopes, vegetation structure, facilities and services, and artificial elements. Distance from the central area of the city towards the more decentralised residential areas (gradient) correlated negatively, implying strong differences in quality factors of parks between the city core and the suburbs. In addition, relatively high correlations between park type, age of park and the socio-economic status of the surrounding neighbourhood were found, indicating that the structural diversity of parks is greater in neighbourhoods with high socio-economic status. 


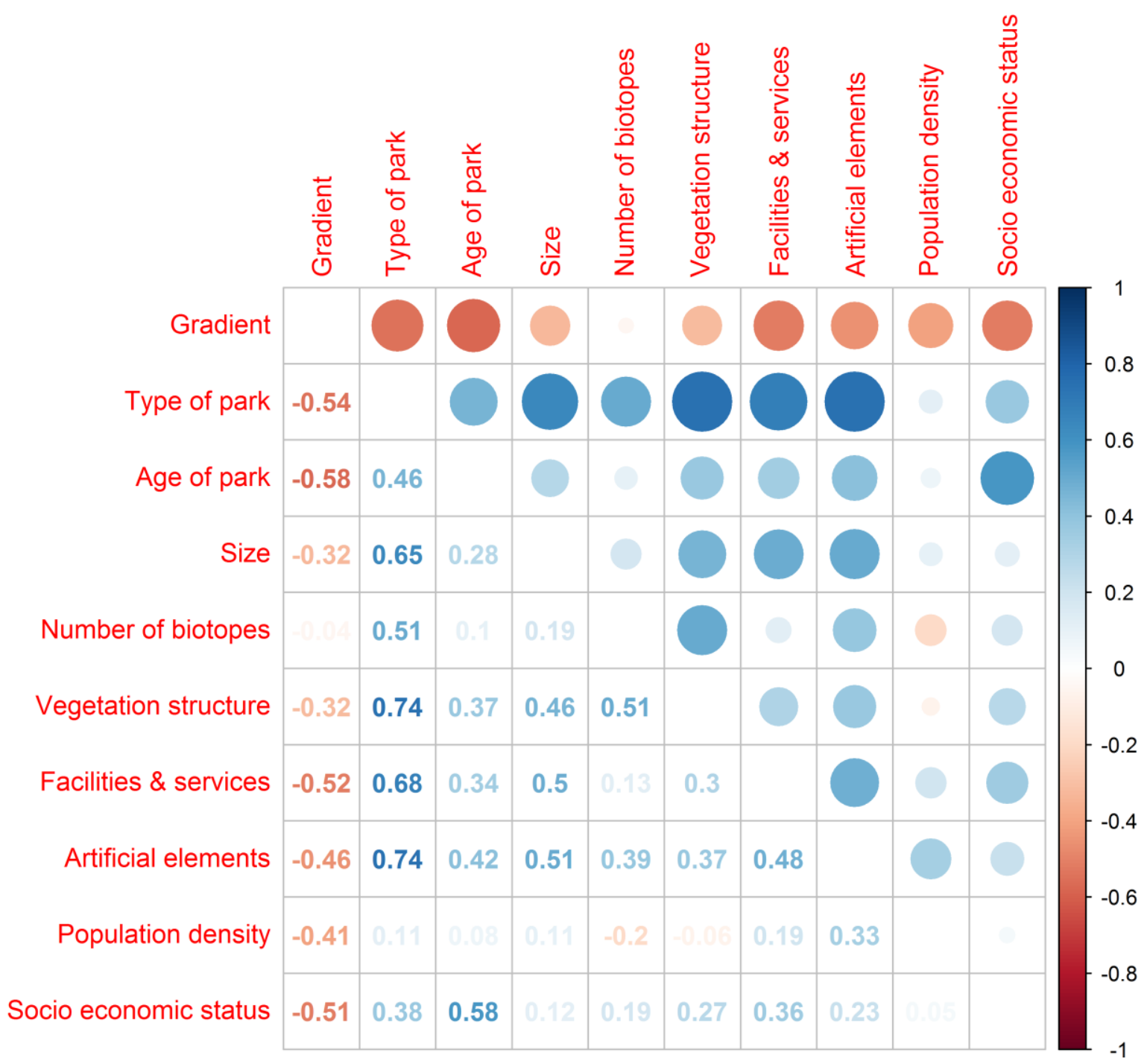

Figure 5. Spearman's rho correlations and significance level between types of parks and park characteristics and surrounding city context: location along the gradient, population density and socio-economic status $(\mathrm{n}=33)$.

To reveal the role of structural diversity of parks in motivating people to use them or have positive experiences during their visit, we analysed differences in them between four park types. Although the results of the Kruskal-Wallis non-parametric test did not reveal significant differences between park types, we could detect slight variations among motivations and enjoyments in different types of parks (Fig. 6A and B). To sum all humanbased motivations together, we revealed that motivations increased strongly with structural diversity, being almost 40 per cent (from $86 \%$ to $141 \%$ ) higher in parks with high structural 
diversity than in parks with low structural diversity. The total sum was higher than $100 \%$, because the same person could give multiple reasons for their visit. Social-based motivations were highest in structurally diverse parks, and relaxation and well-being in parks with medium-high structural diversity. Motivations listed under the environmental domain were most common in parks with moderate or semi-high structural diversity. Location was the most common motivation to visit parks with low structural diversity. We could detect similar kinds of patterns in environmental-based enjoyments as in human-based motivations; however, the increase between parks with low and high structural diversity was not so strong (from $124 \%$ to $148 \%$ ). Nature-based enjoyments in particular increased with the structural diversity of parks. Location was more commonly mentioned in those parks with low levels of structural diversity than in other types of parks. Human-based enjoyments were rather similar in different parks. Location and weather were rather rarely mentioned enjoyments in all four park types.
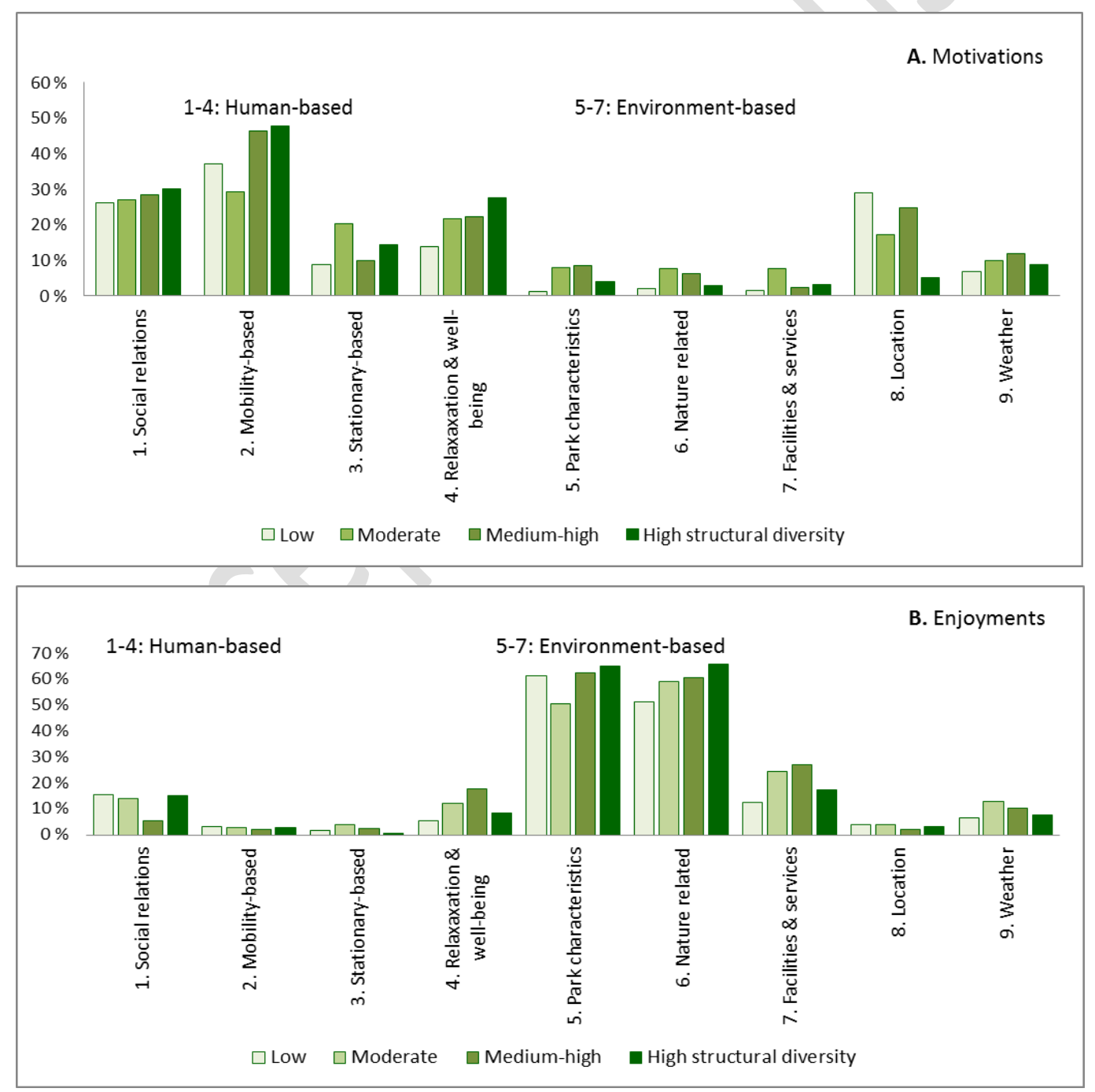
Figure 6. Proportions (\%) of visitors under different themes (1-9) of motivations (A) and enjoyments $(B)$ in four park types $(n=33)$.

Motivations for using parks and enjoyments during visits differed significantly between cities, based on the Kruskal-Wallis non-parametric test (Fig. 7A and B). Cities differed in all tested human-based motivations and enjoyments. Pairwise comparisons revealed that certain cities formed pairs. For example, Berlin and Bucharest were similar in social-related motivations for park use, but Helsinki and Lisbon were different from Berlin and Bucharest. Location as a motivation for park use was similar in the Helsinki-Lisbon pairing and the Berlin-Bucharest pairing, but the importance of location as a motivation for park use differed clearly between the two pairs. Each city had its specific motivation and enjoyment pattern compared to other cities. Bright weather was a commonly mentioned motivation and enjoyed thing in the Helsinki parks. In Lisbon, nature motivated park use more often, and the park visitors enjoyed relaxation and well-being much more often than in the other three cities. In Bucharest, park use was strongly mobility oriented, but visitors enjoyed the nature or park characteristics less often than visitors in other cities. On the contrary, park visitors in Berlin commonly mentioned enjoying variable characteristics of parks.

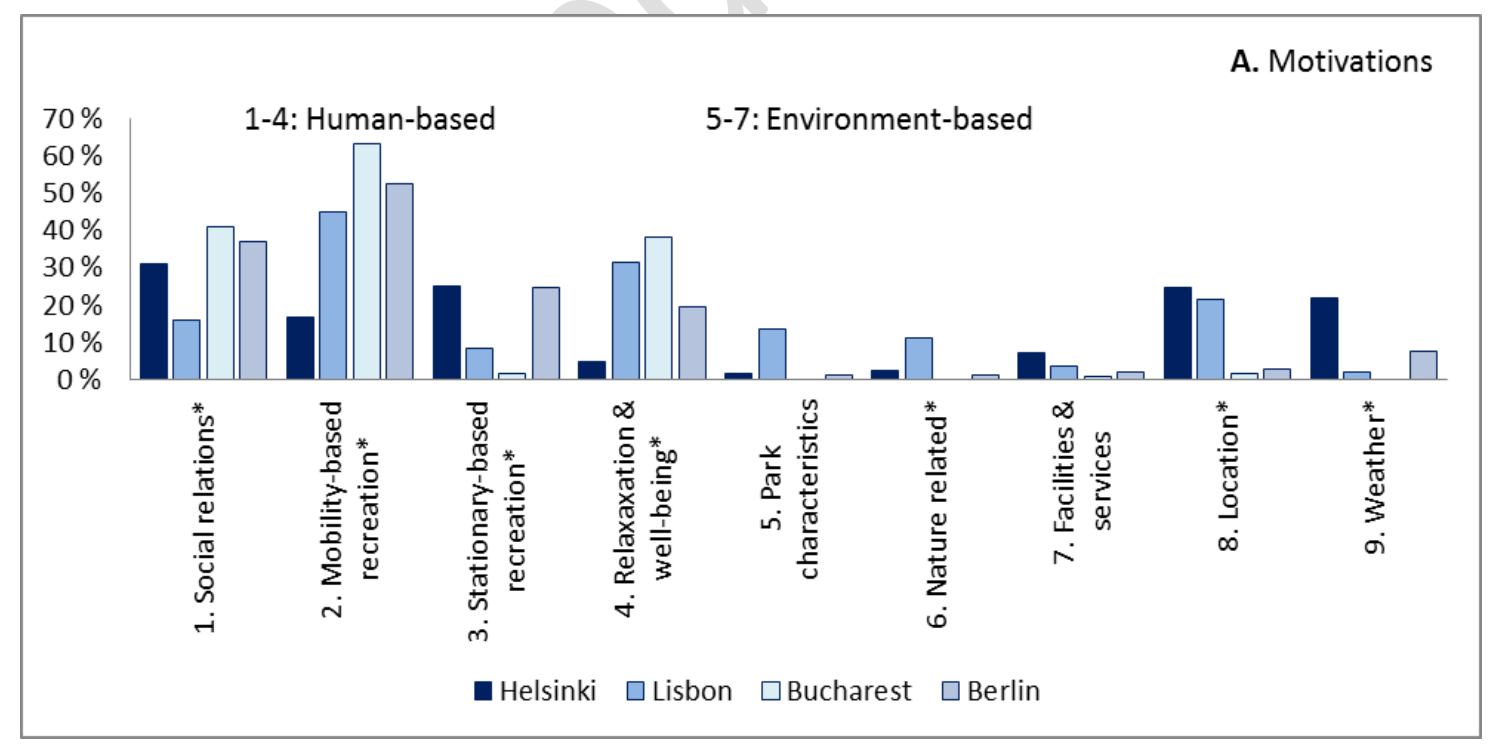




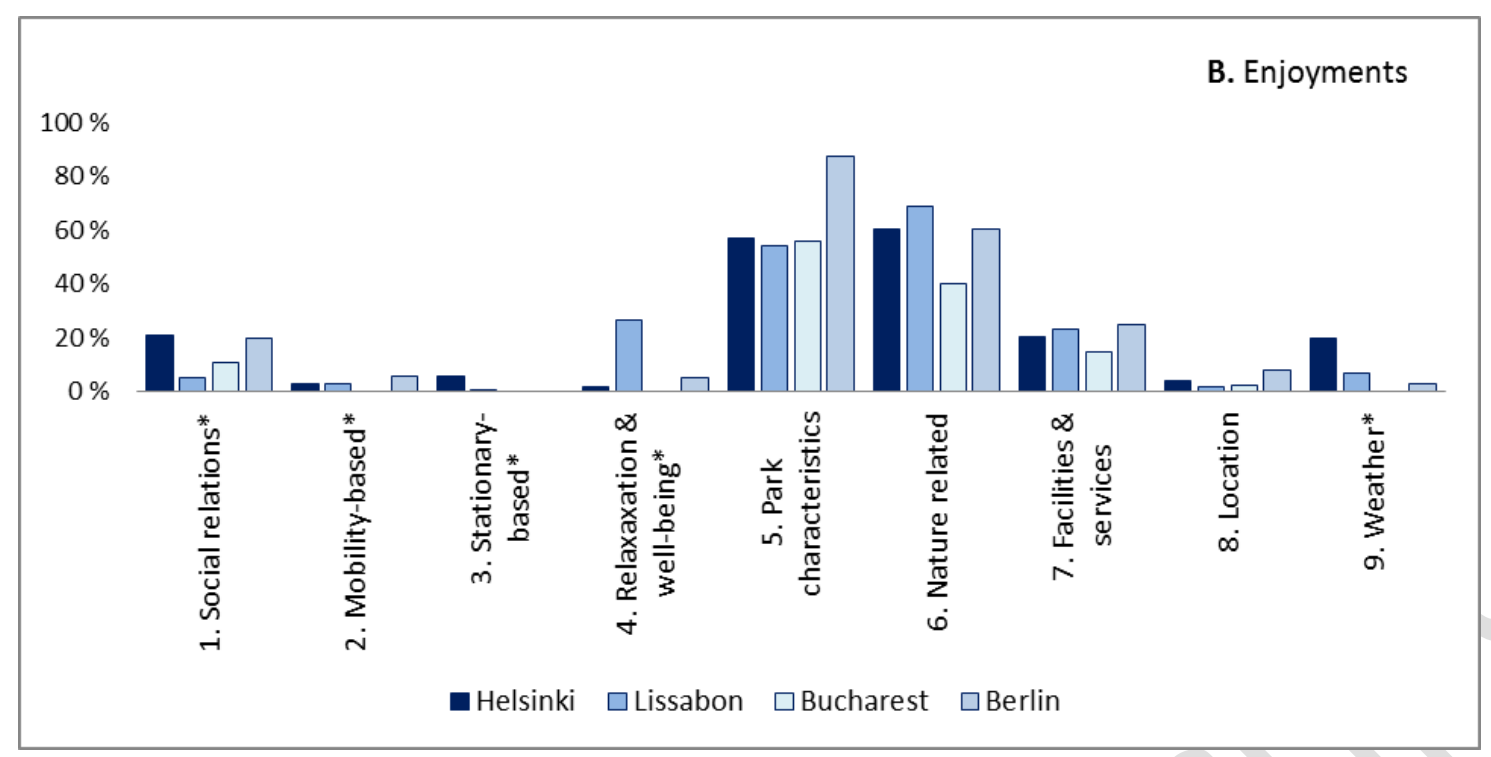

Figure 7. Proportion of visitors (\%) under the nine themes of motivations (A) and enjoyments (B) in the four cities. Significant differences are indicated with dashes $(n=33)$.

In order to reveal whether the specific components of structural diversity, park size or urban context in which the park was situated were associated with motivations or enjoyments, we tested potential correlations between these variables (Table 6). Mentioned motivations, human-based motivations and environment-based enjoyments increased with park size. Biotope richness had a positive correlation with environmental, but a negative correlation with human-based enjoyments. Vegetation structure correlated positively only with motivations, while artificial elements, facilities and services correlated positively with humanbased motivations for park use.

Table 6. Spearman's rho correlations and significance level between variables of structural diversity, surrounding city context (population density and socio-economic status of neighbourhood), motivations and enjoyments $(\mathrm{N}=33)$. 


\begin{tabular}{|c|c|c|c|c|c|c|c|}
\hline Variable & 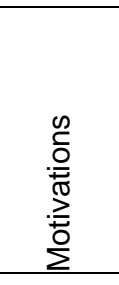 & 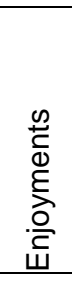 & 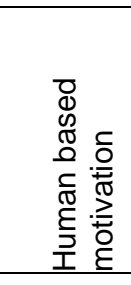 & 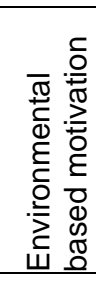 & 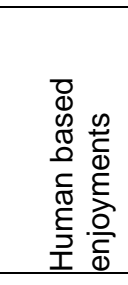 & 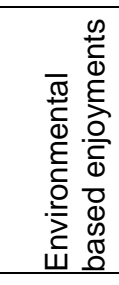 & 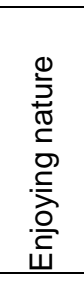 \\
\hline Age of park & n.s. & n.s. & n.s. & n.s. & n.s. & n.s. & n.s. \\
\hline Size (ha) & $0.349^{*}$ & n.s. & $0.459^{* *}$ & n.s. & n.s. & $0.424^{\star}$ & n.s. \\
\hline Number of biotopes & n.s. & n.s. & n.s. & n.s. & $-0.393^{\star}$ & $0.412^{\star}$ & n.s. \\
\hline Vegetation structure & $0.394^{\star}$ & n.s. & n.s. & n.s. & n.s. & n.s. & n.s. \\
\hline Artificial elements & n.s. & n.s. & $0.344^{*}$ & n.s. & n.s. & n.s. & n.s. \\
\hline Facilities and services & n.s. & n.s. & $0.436^{\star}$ & n.s. & n.s. & n.s. & n.s. \\
\hline Population density (500 m) & n.s. & n.s. & $0.552^{\star *}$ & n.s. & n.s. & n.s. & n.s. \\
\hline $\begin{array}{r}\text { Socio-economic status of } \\
\text { neighbourhood }\end{array}$ & n.s. & n.s. & n.s. & n.s. & n.s. & n.s. & n.s. \\
\hline
\end{tabular}

**. Correlation is significant at the 0.01 level (2-tailed).

*. Correlation is significant at the 0.05 level (2-tailed). n.s. Not significant

\section{Discussion and conclusions}

\subsection{Human-based motivations are linked with environment-based enjoyments}

Our place-based study revealed that human-based reasons (e.g. walking and talking, jogging, meeting friends, reading, having lunch) motivated people to use the parks. Despite the fact that environmental features were rarely mentioned as a reason for visiting parks, we found that the structural diversity of parks enhanced different human-based motivations for park use. We will address this content later in the discussion. Our study corroborates earlier findings suggesting that mobility-based recreation (e.g. sports, walking, cycling) along with social activities (e.g. meeting friends, picnicking) are the main things urban parks are used for in Europe, Asia and the Middle East (e.g. Chiesura, 2004; Peters et al., 2010; Schetke et al., 2016; Rall et al., 2017; Fischer et al., 2018b). Fischer et al. (2018b) found that only a minority $(15 \%)$ of visitors used UGS for purely nature-based reasons. We also noticed that nature as a motivation for visiting the park was rarely mentioned and was usually reduced to a single nature element or animals in parks, such as "feeding ducks", implying that the park visitors were more motivated by some specific feature than the overall nature of the park (Voigt and Wurster, 2015; Vierikko and Yli-Pelkonen, 2019). 
Despite the fact that motivations for park use were strongly human-oriented, the majority of park visitors did interact with the local environment through enjoying nature or specific characteristics of the park, supporting the idea that public parks provide opportunities for diverse interaction with nature (Vertovec, 2007; Peters et al., 2010). As we were particularly focusing on diversity of experiences, we counted over 100 aspects that visitors enjoyed during their actual park visits in total. The majority of enjoyments were linked with nature or park characteristics, revealing that park users interact with local environment through multiple senses such as listening ('singing trees' or 'sound of water') or smelling ('scent of park'). Interaction with the local environment may strengthen place attachment and stimulate stewardship towards nature (Kyle et al., 2004; Raymond et al., 2010; Ives et al., 2017).

We revealed complex relationships between different themes of motivations for park use and experiences during the park visit. Those who used parks for social reasons were also very much human-oriented with their enjoyments and interacted less with the place itself. Socialbased motivations seemed to decrease negative experiences, also related to other people, indicating that satisfaction or sensitivity towards disturbing factors during the park visit is also dependent on motivations and not only on environmental factors (e.g. management of park). Social motivations for park use have been found to have a positive effect on social cohesion in parks in the UK (Kazmierczak, 2010). Social relations as a motivation did not correlate with the park being located close to home, while weather and environmental-based motivations did, indicating that the majority of visitors who were using parks for social reasons, e.g. meeting friends or having a picnic, preferred a park further away for meeting their human-based needs. These parks, as discussed above, are usually structurally diverse, well-known and located in the central area.

It was not surprising that visitors who visited the park for nature-related or parkcharacteristics reasons enjoyed nature more overall than those who visited for human-based reasons. We also noted that those who visited for environmental reasons enjoyed their visits overall more than those who were motivated by human-based reasons. Interestingly, visitors whose motivation for park use was weather-based (e.g. sun bathing) or who visited to use facilities or services enjoyed the nature to a lesser extent and also perceived more disturbing factors than visitors who visited the park for the place itself (i.e. park characteristics). Furthermore, we found that those who visited to relax or who actively moved around in the park (e.g. walking a dog) enjoyed nature more often than those who visited mainly for social 
reasons. Close-to-home location and environmental-based motivations were commonly mentioned together implying that nearby UGS has an important role for supporting humannature interaction (Soga et al., 2014). Our findings supported earlier studies which stated that when park visitors were seeking space to enjoy quietness, nature or fresh air, close-to-home green spaces became more important than parks situated further away (Soga et al., 2014; Vierikko et al., 2017a).

\subsection{Structural diversity of parks is important for uses and experiences}

We revealed that human-based motivations increased clearly in line with the structural diversity of the park, but not with environment-based motivations. We also found that a higher proportion of visitors mentioned enjoying nature in structurally diverse parks. Relaxation motives were more often linked with nature enjoyments than other types of human-based motivations. Previous studies have shown that species richness and structural diversity of UGS matters for perceived benefits, e.g. restoration and well-being (Voigt et al., 2014; Ives et al., 2017). If the park is not diverse in material characteristics, it does not necessarily attract people to visit it (McCormack et al., 2010). Fischer et al. (2018b) discovered in their European-scale study that citizens value plant species richness highly in different types of UGS, indicating that biodiversity matters for positive experiences when using public parks. Kabisch \& Haase (2014) found in their case study that the majority of urban residents in Berlin particularly desired structural diversity in green spaces (facilities, large trees, water elements).

We found a positive relationship between human-based motivations, environment-based enjoyments and park size, supporting the theory of urban park geography: the larger the park, the more diverse the human values (Brown, 2008). However, park size did not correlate with nature enjoyments, suggesting that smaller parks can also stimulate nature experiences, and having diverse vegetation and biotopes is more important in developing interactions with the surrounding environment than the size of the park. Parks with diverse vegetation structure, large trees and many biotopes can offer diverse nature experiences, improve restorative benefits, and enhance human connectedness with local nature (Nisbet et al., 2009; Wood et al., 2018), especially among urban residents who do not have either the opportunity or the willingness to visit large recreational areas or nature areas outside the city. We found a positive correlation between biotope richness and environmental-based enjoyments. 
Biologically diverse parks can prevent the possible disconnection of residents living in densely populated areas from local nature and its knowledge, protection and conservation (Celis-Diez et al., 2017), especially if their favourite places are in artificial, human-made urban environments without any natural elements (Tyrväinen et al., 2007).

Our typology of materialised BCD indicated that public parks are neither independent nor neutral spaces from the surrounding urban context, but their tangible characteristics manifest the socio-economic status, as well as the socio-historical context of the surrounding neighbourhood (Byrne \& Wolch, 2009). Our findings support arguments that the location of a park (central or peripheral) can influence park uses and perceptions of visitors (Voigt et al., 2014). Furthermore, our findings corroborate earlier results (e.g. de la Barrera et al., 2016), which reveal that parks located away from city centres and in neighbourhoods with low socioeconomic status are not necessarily as structurally diverse (having less vegetation, especially fewer trees) as parks in more affluent urban areas. This raises the concern of inequity in UGS planning between different city districts, if high-quality and biologically rich parks are located in the wealthy neighbourhoods (Kabisch \& Haase, 2014; Rigolon et al., 2018). Older and larger parks as well as parks with diverse structural characteristics were mainly located in central areas in the studied cities. These parks invited people to use them for several humanbased reasons, and especially for social relations (picnicking, meeting other people, playing) and relaxation, and offered visitors a more diverse environment to enjoy than parks situated in neighbourhoods with low socio-economic status.

\subsection{Cities differed in their park uses and experiences}

Cities differed greatly in terms of people's motivations to use them and their experiences during visits. The close to home location was a commonly mentioned motivation for park use in Helsinki and Lisbon (25\% and 21\%), despite residents in these two capitals are in very different situations in terms of UGS supply - in Lisbon only $19 \%$ of land surface is recreational UGS compared to Helsinki with $47 \%$ of recreational UGS (Davies, 2015; Vierikko et al., 2014). One interesting difference was that in Helsinki, visitors commonly used parks as shortcuts on their way to somewhere else, while in Lisbon visitors went to parks near their homes to enjoy nature, walk around and relax. On the contrary, nature was a rarely mentioned motivation to use public parks in Helsinki, as the majority (79\%) had very good access to their nearest UGS $(300 \mathrm{~m})$ and almost half of the residents had easy access to urban 
forests, which are commonly valued and visited for nature experiences (Neuvonen et al., 2007; Vierikko et al., 2017b; Harlio \& Tuhkanen, 2018). In Berlin and Bucharest, social relations linked with mobility- (walking and talking) and stationary-based (picnicking with friends) activities were commonly mentioned motivations for visiting. However, in Bucharest visitors reported far fewer enjoyments than respondents in Berlin, where the majority of visitors enjoyed park characteristics and nature. All three Berlin parks were structurally diverse, supporting local residents' desire for quality factors of parks, as identified by Kabisch $\&$ Haase (2014).

\section{Conclusions and limitations of the study}

We applied the BCD concept to explore interactions between people and the environment. The Europe-wide character of this study brought up novel knowledge on the interlinkages between motivations, experiences, parks and surrounding neighbourhoods across the continent, which are highly interesting and have not been reported by previous research. We found that cities differed greatly with their lived BCD, implying that day-to-day practices of people using and experiencing UGS can be very different in different geographical contexts. As we included only three parks in Berlin and five in Bucharest in our study, compared to the 12 parks in Helsinki and Lisbon covering the complete urban gradient, the results should be interpreted with caution. One of the core findings was that even when nature was not the primary reason for visiting a park, it was one of the most commonly enjoyed things, revealing the importance of contact with nature, even if not on purpose, and independently of the type of park. Therefore, it is very important to have biologically diverse public parks in different urban contexts in order to combat the loss of nature experiences (Soga \& Gaston, 2016).

We revealed that interaction between uses, experiences and local environments is a complex process influenced by materialised characteristics of parks, but also by the surrounding urban context. Our study showed that urban green spaces are not independent or neutral, but their materialised BCD reflect their surrounding neighbourhoods, as well as the socio-cultural context of the geographical location of the green space. Designing attractive parks with diverse structural elements - especially with high biodiversity - in neighbourhoods with low socio-economic status would support local people to use them for multiple reasons, thus enhancing social cohesion and the well-being of different social groups (Cattell et al., 2008; Capaldi et al., 2014; Kuo, 2015). Analysing the relationship between materialised and lived 
BCD - and taking the local context into account - will help us to design, plan and manage for more just and inclusive UGS and support social justice and diverse interactions between culture(s) and nature in public parks (Madureira and Andresen, 2013; Rodriguez et al., 2016).

\section{Acknowledgements}

This research was supported by the European Commission's $7^{\text {th }}$ Framework Programme Grant GREEN SURGE collaborative project, FP7-ENV.2013.6.2-5-603567. The Romanian research was supported by a grant from the Romanian National Authority for Scientific Research, CNCS - UEFISCDI (http://uefiscdi.gov.ro), project number PN-III-P4-ID-PCE2016-0635. We thank Dr Stephen Venn for language checking and Thilo Wellmann for supporting the work on illustrations.

\section{References}

Balvanera, P., Daw, T.M., Gardner, T.A., Martin-López, B., Nortström, A. et al. 2017. Key features for more successful place-based sustainability research on social-ecological systems: a Programme on Ecosystem Change and Society (PECS) perspective. Ecology and Society 22(1), 14. doi: 10.5751/ES-08826-220114.

Bertram, C., Rehdanz, K. 2015. The role of urban green space for human well-being. Ecological Economics 120, 139-152. doi: 10.1016/j.ecolecon.2015.10.013.

Botzat, A., Fischer, L.K., Kowarik, I. 2016. Unexploited opportunities in understanding liveable and biodiverse cities. A review on urban biodiversity perception and valuation. Global Environmental Change 39, 220-233.

Bratman, G. N., Hamilton, J. P., Daily, G. C. 2012. The impacts of nature experience on human cognitive function and mental health. Annals of the New York Academy of Sciences, 1249(1), 118-136.

Brown, G. 2008. Theory of Urban Park Geography. Journal of Leisure Research 40(4), 589607. doi: 10.1080/00222216.2008.11950154.

Buizer, M., Elands, B. and Vierikko, K. 2016. Governing cities reflexively - The biocultural diversity as an alternative for ecosystem services. Environmental Science \& Policy 62, 7-13. doi: 10.1016/j.envsci.2016.03.003.

Byrne, J., Wolch, J. 2009. Nature, race, and parks: Past research and future directions for geographic research. Progress in Human Geography 33(6), 743-765. 
Capaldi C. A., Dopko R. L., Zelenski J. M. 2014. The relationship between nature connectedness and happiness: a meta-analysis. Frontiers in Psychology 5, 976. doi: 10.3389/fpsyg.2014.00976

Cattell, V., Dines, N.,Gesler, W., Curtis, S. 2008. Mingling, observing, and lingering: Everyday public spaces and their implications for well-being and social relations. Health \& Place 14, 544-561.

Celis-Diez, J.L., Munoz, C.E., Abades, S., Marquet, P.A., Armesto, J.J. 2017. Biocultural Homogenization in Urban Settings: Public Knowledge of Birds in City Parks of Santiago, Chile. Sustainability 9(4), 485. doi: 10.3390/su9040485.

Chiesura, A. 2004. The role of urban parks for the sustainable city. Landscape and Urban Planning 68(1), 129-138. doi: 10.1016/j.landurbplan.2003.08.003.

Cvejić, R., Eler, K., Pintar, M., Železnikar, Š., Haase, D., Kabisch, N., et al. 2015. A typology of urban green spaces, ecosystem provisioning services, and demands. EU FP7 project GREEN SURGE, deliverable D3.1. Retrieved from www.greensurge.eu.

Dallimer, M., Irvine, K. N., Skinner, A. M. J., Davies, Z. G., Rouquette, J. R., Maltby, L. L., et al. 2012. Biodiversity and the feel-good factor, understanding associations between selfreported human well-being and species richness. BioScience 62(1), 47-55.

Davies, C., Hansen, R., Rall, E., Pauleit, S., Lafortezza, R., De Bellis, Y., et al. 2015. The status of European green space planning and implementation based on an analysis of selected European city-regions. EU FP7 project GREEN SURGE, deliverable D5.1. Retrieved from www.greensurge.eu.

de la Barrera, F., Reyes-Paecke, S., Banzhaf, E. 2016. Indicators for green spaces in contrasting urban settings. Ecological Indicators 62, 212-219.

doi:10.1016/j.ecolind.2015.10.027

Elands, B., Wiersum, K., Buijs, A., Vierikko, K. 2015. Policy interpretations and manifestations of biocultural diversity in urbanized Europe: Conservation of lived biodiversity. Biodiversity and Conservation 24, 3347-3366. doi: 10.1007/s10531-015-1014-5.

Elands, B.H.M., Peters, K.B.M., Vries, S. de 2018a. Promoting social cohesion - increasing wellbeing. In: van den Bosch, M. and Bird, M. (Eds.), Oxford Textbook of Nature and Public Health. Oxford University Press, p. 116-121.

Elands, B.H.M., Vierikko, K., Andersson, E., Fischer, L.K., Gonçalves, P., Haase, D., Kowarik, I., Luz, A.C., Niemelä, J., Santos-Reis, M., Wiersum, K.F. 2018b. Biocultural diversity: A novel concept to assess human-nature interrelations, nature conservation and 
stewardship in cities. Urban Forestry \& Urban Greening 40, 29-34. doi:

10.1016/j.ufug.2018.04.006.

Fischer, L., Honold, J., Cvejic, R., Delshammar, T., Hilbert, S., Lafortezza, R., Nastran, M., Busse Nielsen, A., Pintar, M., van der Jagt, A., Kowarik, I. 2018a. Beyond green: Broad support for biodiversity in multicultural European cities. Global Environmental Change 49, 35-45. doi.org/10.1016/j.gloenvcha.2018.02.001

Fischer, L.K., Honold, J., Botzat, A., Brinkmeyer, D., Cvejić, R., Delshammar, T., Elands, B., Haase, D., Karle, S.J., Kabisch, N., Lafortezza, R., Nastran, M., Nielsen, A-B., van der Jagt, A.P., Vierikko, K., Kowarik, I. 2018b: Recreational ecosystem services in European cities: sociocultural and geographic context matters for park use. Ecosystem Services 31 (Part C), 455-461. doi: 10.1016/j.ecoser.2018.01.015.

Fuller, R. A., Irvine, K. N., Devine-Wright, P., Warren, P. H., Gaston, K. J. 2007.

Psychological benefits of green space increase with biodiversity. Biology Letters 3, 390- 394.

Gustafsson, P. 2001. Meanings of Place: Everyday Experience and Theoretical Conceptualizations. Journal of Environmental Psychology 21, 5-16.

Hansen, R., Pauleit, S., 2014. From Multifunctionality to Multiple Ecosystem Services? A Conceptual Framework for Multifunctionality in Green Infrastructure Planning for Urban Areas. AMBIO 43, 516-529.

Hansen, R., Werner, R., Santos, A., Luz, A., Száraz, L., Tosics, I., et al. 2016. Advanced urban green infrastructure planning and implementation. EU FP7 project GREEN SURGE, Deliverable D5.2. Retrieved from www.greensurge.eu.

Harlio, A., Tuhkanen, H. 2018. NATOURS 2016-2018 kaupunkiluontohanke Helsinki \& Tallinna (Urban nature project in Helsinki and Tallinn). Oral presentation 3.5.2018.

Hartig, T., Mitchell, R., de Vries, S., Frumkin, H., 2014. Nature and health. Annual Review of Public Health 35, 207-228.

Hoyle, H., Hitchmough, J., Jorgensen, A. 2017. All about the 'wow factor'? The relationships between aesthetics, restorative effect and perceived biodiversity in designed urban planting. Landscape and Urban Planning 164, 109-123.

Hoyle, H., Jorgensen, A., Hitchmough, J. 2019. What determines how we see nature? Perceptions of naturalness in designed urban green spaces. People and Nature 1(2), 167-180. Doi: $10.1002 /$ pan3.19.

Ives, C.D., Giusti, M., Fischer, J., Abson, D., Klaniecki, K...2017. Human-nature connection: a multidisciplinary review. Current Opinion in Environmental Sustainability 27-27, 106-113. 
Kabisch, N., Haase, D. 2014. Green justice or just green? Provision of urban green spaces in Berlin, Germany. Landscape and Urban Planning 122, 129-139. doi: 10.1016/j.landurbplan.2013.11.016

Kabisch, N., Qureshi, S., Haase, D. 2014. Urban nature: Human-environment interactions in urban green spaces - contemporary issues and future prospects. Environmental Impact Assessment Review 50, 25-34. doi: 10.1016/j.eiar.2014.08.007.

Kazmierczak, A.E. 2010. Urban Green Spaces and Social Cohesion. Doctoral thesis, School of the Built Environment, University of Salford, UK.

Konijnendijk, C.C., Annerstedt, M., Nielsen, A.B., Maruthaveeran, S. 2013. Benefits of urban parks: A systematic review. A Report for IFPRA. Copenhagen \& Alnarp, Denmark. 68 pp.

Kuo, M. 2015. How might contact with nature promote human health? Promising mechanisms and a possible central pathway. Frontiers in Psychology 6, 1-8. doi:10.3389/fpsyg.2015.01093

Kyle, G., Mowen, A., Tarrant, M. 2004. Linking place preferences with place meaning: An examination of the relationship between place motivation and place attachment. Journal of Environmental Psychology 24, 439-454.

Madureira, H., Andresen, T. 2014. Planning for multifunctional urban green infrastructures: Promises and challenges. URBAN DESIGN International 19(1), 38-49. doi: 10.1057/udi.2013.11.

Maffi, L. 2012. Biocultural diversity conservation. Earthscan, UK, p. 5.

Matz, C.J., Stieb, D.M., Brion, O. 2015. Urban-rural differences in daily time-activity patterns, occupational activity and housing characteristics. Environmental Health 14, 88. doi: 10.1186/s12940-015-0075-y

McCormack, G.R., Rock, M., Toohey, Hignell, D. 2010. Characteristics of urban parks associated with park use and physical activity: a review of qualitative research. Health Place 16(4), 712-726.

Millard, A., 2010. Cultural aspects of urban biodiversity. In: Müller, N., Werner, P., Kelcey, J.G. (Eds.), Urban biodiversity and design. Wiley-Blackwell, UK, pp. 56-80. 
Neuvonen, M., Sievänen, T., Tönnes, S., Koskela, T., 2007. Access to green areas and the frequency of visits - a case study in Helsinki. Urban Forestry \& Urban Greening 6, 235-247. 10.1016/j.ufug.2007.05.003.

Nielsen, A., van den Bosch, M., Maruthaveeran, S., Konijnendijk van den Bosch, C. 2014. Species richness in urban parks and its drivers: A review of empirical evidence. Urban Ecosystems 17(1), 305-327.

Nisbet, E.K., Zelenski, J.M., Murphy, S.A. 2009. The nature relatedness scale: Linking individuals' connection with nature to environmental concern and behaviour. Environment and Behavior 41, 715-740.

Palliwoda, J., Kowarik, I., von der Lippe, M. 2017. Human-biodiversity interactions in urban parks: The species level matters. Landscape and Urban Planning 157, 394-406.

Pauleit, S., Hansen, R., Lorance Roll, E., Zölch, T., Andersson, E., Luz, A. K., Száraz, L., Tosics, I. and Vierikko, K. 2017. Urban Landscapes and Green Infrastructure. Oxford Research Encyclopedia of Environmental Science. Environment and Human Health, 57 p. doi: 10.1093/acrefore/9780199389414.013.23.

Peters, K., Elands, B., Buijs, A. 2010. Social interactions in urban parks: Stimulating social cohesion? Urban Forestry \& Urban Greening, 9(2), 93-100.

Pretty, J., Adams, B., Berkes, F., et al., 2009. The intersections of biological diversity and cultural diversity: towards integration. Conservation \& Society 7, 100-112.

Pungetti G., 2013. Biocultural Diversity for Sustainable Ecological, Cultural and Sacred Landscapes: The Biocultural Landscape Approach. In: Fu B., Jones K. (Eds.) Landscape Ecology for Sustainable Environment and Culture. Springer, Dordrecht, pp. 55-76.

Puppim de Oliveira, J.A., Balaban, O., Doll, C.N.H., Moreno-Peñaranda, R., Gasparator, A., Iossifova, D., Suwa, A. 2011. Cities and Biodiversity: Perspectives and governance challenges for implementing the convention on biological diversity (CBD) at the city level. Biological Conservation 144, 1302-1313.

Qiu, L., Lindber, S., Nielsen, A.B. 2013. Is biodiversity attractive? - on-site perception of recreational and biodiversity values in urban green space. Landscape and Urban Planning 119, 136-146. 10.1016/j.landurbplan.2013.07.007.

Rall, E., Bieling, C., Zytynska, S., Haase, D. 2017. Exploring city-wide patterns of cultural ecosystem service perceptions and use. Ecological Indicators 77, 80-95. doi:

10.1016/j.ecolind.2017.02.001. 
Raymond, C., Brown, G. and Weber, D. 2010. The Measurement of Place Attachment: Personal, Community, and Environmental Connections. Journal of Environmental Psychology 30(4), 422-434.

Rigolon, A., Browning, M., Jennings, V. 2018. Inequities in the quality of urban park systems: An environmental justice investigation of cities in the United States. Landscape and Urban Planning 178, 156-169. doi: 10.1016/j.landurbplan.2018.05.026

Rodriguez, M.C., Di Virgilio, M.M. 2016. A city for all? Public policy and resistance to gentrification in the southern neighborhoods of Buenos Aires. Urban Geography 37(8), 1215 1234. doi: 10.1080/02723638.2016.1152844.

Schetke, S., Qureshi, S., Lautenbach, S., Kabisch, N. 2016. What determines the use of urban green spaces in highly urbanized areas? - Examples from two fast growing Asian cities. Urban Forestry \& Urban Greening 16, 150-159. doi: 10.1016/j.ufug.2016.02.009.

Sixsmith, J. 1986. The meaning of home: An exploratory study of environmental experience. Journal of Environmental Psychology 6, 281-298.

Soga, M., Yamaura, Y., Koike, S., Gaston, K. 2014. Land sharing vs. land sparing: does the compact city reconcile urban development and biodiversity conservation? Journal of Applied Ecology 51(5), 1378-1386. doi.org/10.1111/1365-2664.12280.

Soga, M., Gaston. K.J., 2016. Extinction of experience: the loss of human-nature interactions. Frontiers in Ecology and the Environment 14, 94-101. doi: 10.1002/fee.1225.

Stokols, D. 2018. Social Ecology in the Digital Age: Solving Complex Problems in a Globalized World. Elsevier, London.

Sussams, L.W., Sheate, W.R., Eales, R.P. 2014. Green infrastructure as a climate change adaptation policy intervention: Muddying the waters or clearing a path to a more secure future? Journal of Environmental Management 147, 184-193. doi: 10.1016/j.jenvman.2014.09.003.

Taylor, K., Lennon, J., 2011. Cultural landscapes: a bridge between culture and nature? International Journal of Heritage Studies 17, 537-554.

Tyrväinen, L., Silvennoinen, H., Korpela, K., Ylen, M. 2007. Luontomatkailu, Metsät ja Hyvinvointi (The Meaning of Nature for Urban Residents and Effects on Psychological WellBeing). METLA Working Paper 52. Vantaa: Finnish Forest Research Institute. (in Finnish).

Vertovec, S. 2007. Super-diversity and its implications, Ethnic and Racial Studies 30(6), 1024-1054. doi: 10.1080/01419870701599465. 
Vierikko, K., Niemelä, J., Salminen, J., Jalkanen, J. ja Tamminen, N. 2014. Sustainable green infrastructure of Helsinki - urban ecological research report and recommendations for the Helsinki master plan 2014. Helsingin kaupunkisuunnitteluviraston yleissuunnitteluosaston selvityksiä 2014. 113 s. (In Finnish with English summary) Retrieved form www.hel.fi/hel2/ksv/julkaisut/yos_2014-27.pdf.

Vierikko, K. H., Birgit, E., Niemelä, J. K., Andersson, E., Buijs, A., Fischer, L., Haase, D., Kabisch, N., Kowarik, I., Luz, A. C., Olafsson Stahl, A., Száraz, L., Van der Jagt, A., Konijnendijk Van-den Bosch, C. 2016. Considering the ways biocultural diversity helps enforce the urban green infrastructure in times of urban transformation. Current Opinion in Environmental Sustainability 22, 7-12. doi: 10.1016/j.cosust.2017.02.006.

Vierikko, K., Andersson, E., Branquinho, C., Elands, B., Fischer, L. K., Goncalves, P., Grilo, F., Haase, D., Ioja, C., Kowarik, I., Lindgren, J. M., Mendes, R., Niemelä, J. K., Pieniniemi, M., Principe, A., Puttonen, M., Santos-Reis, M., Teixeira, D., Vieira, J., Yli-Pelkonen, V. J. 2017a Identifying, Quantifying and Qualifying Biocultural Diversity: Assessment of Biocultural Diversity. GREEN SURGE, Deliverable 2.3. Retrieved from www.greensurge.eu.

Vierikko, K., Elands, B., Goncalves, P., Luz, A.C., Andersson, E., Haase, D., Fischer, L., Kowarik, I., Niemelä, J., 2017b. BCD: Linkages between people and nature - database, typology and indicators. GREEN SURGE, Milestone 22. Retrieved from www.greensurge.eu.

Vierikko, K., Yli-Pelkonen, V. 2019. Seasonality in recreation supply and demand in an urban lake ecosystem in Finland. Urban Ecosystems 22(4), 769-783.

Voigt, A., Kabisch, N., Wurster, D., Haase, D., Breuste, J. 2014. Structural diversity as a key factor for the provision of recreational services in urban parks - a new and straightforward method for assessment. AMBIO 43(4), 480-491.

Voigt, A., Wurster, D. 2015. Does diversity matter? The experience of urban nature's diversity: Case study and cultural concept. Ecosystem Services 12, 200-206. doi: 10.1016/j.ecoser.2014.12.005.

White, R. 2004. From wilderness to hybrid landscapes: the cultural turn in environmental history. The Historian 66, 557-564.

Wood, E., Harsant, A., Dallimer, M., Cronin de Chavez, A., McEachan, R., \& Hassall, C. 2018. Not All Green Space Is Created Equal: Biodiversity Predicts Psychological Restorative Benefits From Urban Green Space. Frontiers in Psychology 9, 2320.

doi:10.3389/fpsyg.2018.02320 